\title{
Pengaruh Multinutrisi Blok (MNB) sebagai Pakan Pelengkap terhadap Kadar Albumin, Globulin dan Perbandingan A/G pada Kambing Lokal
}

\author{
The Effect of Multi Nutrient Block (MNB) as Supplementary Feed on Albumin, Globulin \\ Levels and the Ratio of $A / G$ in Local Goats
}

\author{
A.B. Iskandar, R. I. Pujianingsih ${ }^{1}$ dan Widiyanto ${ }^{2}$ \\ ${ }^{1}$ Laboratorium Teknologi Pakan Universitas Diponegoro, Semarang dan \\ ${ }^{2}$ Laboratorium Ilmu Nutrisi Ternak Universitas Diponegoro, Semarang \\ Fakultas Peternakan dan Pertanian Universitas Diponegoro, Semarang Kode Pos 50275 \\ Corresponding email: iskandarbudi1@gmail.com
}

\begin{abstract}
This study aimed to examine the effect of multi nutrient block (MNB) as supplementary feed on goat productivity levels reflected through albumin, globulins levels and A / G ratio in blood serum. The use of local goats aimed to increase the level of productivity of local goats which were considered quite low. This research was conducted in the village of Kalisidi, Semarang district and analysis of blood serum in the IBL Semarang laboratory. Local goats evaluated were albumin, globulins and the A / G ratio in their blood serum to determine whether the administration of MNB had a significant effect on the level of productivity. Twelve (12) local goats were kept in individual cages and divided into three groups containing 4 individuals based on body weight 17.5 $20 \mathrm{~kg}$ (Group I), 15 - $16.5 \mathrm{~kg}$ (Group II), 13,5 - $15 \mathrm{~kg}$ (Group III). Each group was given a different ration according to the needs of each group, in which rations were treated without MNB (Treatment I) and rations with the addition of MNB as much as 5, 10, and $15 \mathrm{~g}$ (Treatment II, III, and IV), respectively. Goat blood samples were taken and analyzed to determine the effect on albumin, globulin levels and A / G ratio due to treatment. The results of the analysis data were tested for significance using ANOVA, if the results were significantly different, they would be further tested by Duncan's New Multiple Range Test (MRT) test. The results showed that giving MNB levels with different amounts $(0,5,10$ and $15 \mathrm{~g})$ had no significant effect $(\mathrm{P}>0.05)$ on albumin levels, globulins and the ratio of A / G in blood serum to local goats. It can be concluded that the giving of MNB did not significantly affect livestock productivity reflected through the level of digestion (albumin) and improvement in health (globulin).
\end{abstract}

Key words : MNB, ratios, albumin, globulin

\begin{abstract}
ABSTRAK
Penelitian ini bertujuan untuk mengkaji pengaruh pakan pelengkap multinutrien blok (MNB) terhadap tingkat produktivitas kambing yang tercermin melalui kadar albumin, globulin dan perbandingan A/G dalam serum darah. Penggunaan kambing lokal bertujuan untuk meningkatkan tingkat produktivitas kambing lokal yang dinilai cukup rendah. Penelitian ini dilakukan di desa Kalisidi, kabupaten Semarang dan analisis serum darah di laboratorium IBL Semarang. Kambing lokal dievaluasi kadar albumin, globulin dan perbandingan A/G di dalam serum darahnya untuk mengetahui apakah pemberian MNB berpengaruh nyata terhadap tingkat produktivitas. 12 ekor kambing lokal dipelihara dalam kandang individu dan dibagi kedalam tiga kelompok berisi 4 ekor berdasarkan bobot badan 17,5 - $20 \mathrm{~kg}$ (Kelompok I), 15 - 16,5 kg (Kelompok II), 13,5 - 15 (Kelompok III). Tiap kelompok diberi ransum yang berbeda sesuai dengan kebutuhan tiap kelompok, yang didalamnya diberi perlakuan ransum tanpa MNB (perlakuan I) dan ransum dengan penambahan MNB sebanyak 5, 10, dan 15 gram (perlakuan II, III, dan IV). Sampel darah kambing diambil dan dianalisis untuk mengetahui besar pengaruh kadar albumin, globulin dan perbandingan A/G akibat perlakuan. Data hasil analisis diuji signifikasinya menggunakan ANOVA, apabila hasilnya berbeda nyata maka akan diuji lebih lanjut dengan uji Duncan's New Multiple Range Test (MRT). Hasil penelitian menunjukkan bahwa pemberian level MNB dengan jumlah yang berbeda $(0,5,10$ dan $15 \mathrm{~g}$ ) tidak berpengaruh nyata $(\mathrm{P}>0,05)$ terhadap kadar albumin, globulin dan perbandingan $\mathrm{A} / \mathrm{G}$ dalam serum darah kambing lokal. Dapat disimpulkan bahwa pemberian MNB tidak berpengaruh nyata terhadap produktivitas ternak tercermin melalui tingkat kecernaan (albumin) dan peningkatan kesehatan (globulin).
\end{abstract}

Kata kunci : MNB, perbandingan, albumin, globulin 


\section{PENDAHULUAN}

Kambing merupakan salah satu jenis ternak ruminansia kecil yang cukup baik dalam mengkonversi pakan menjadi produk terutama daging. Produktivitas ternak dipengaruhi oleh genetik $40 \%$ dan lingkungan $60 \%$ berupa pakan, suhu dan kelembaban, intensitas cahaya, kesehatan dan lainnya (Kurnianto, 2010). Kecukupan nutrien dan kesehatan merupakan salah satu faktor lingkungan yang pengaruhnya cukup besar terhadap tingkat produktivitas ternak. Indonesia memiliki dua musim yaitu pada musim kemarau dan musim penghujan, pada musim kemarau ketersediaan hijauan cenderung turun secara drastis. Hal inilah yang menyebabkan penurunan asupan nutrien pada kambing saat musim kemarau, sehingga kambing cenderung kekurangan nutrien yang menyebabkan produksinya turun. Konsumsi pakan yang rendah menyebabkan gangguan metabolik dan penurunan kekebalan tubuh pada hewan. Oleh karena itu perlu adanya supply nutrien lengkap yang dapat meningkatkan produktivitas ternak dan menjaga daya tahan tubuh ternak. Melalui perbaikan status nutrisi diharapkan dapat meningkatkan produktivitas kambing.

Penambahan MNB ke dalam ransum adalah sebagai pakan pelengkap. Pakan pelengkap bertujuan untuk meningkatkan pemanfaatan yang lebih efisien dari pakan yang berkualitas buruk. Harapannya kambing akan meningkat produktivitasnya dan meningkat juga tingkat kesehatannya, sehingga mendapatkan keuntungan yang lebih. Pakan pelengkap berfungsi untuk meningkatkan nafsu makan, meningkatkan produktivitas, meningkatkan efisiensi pakan dan meningkatkan nutrien tertentu yang defisien (Faizal, 2008). MNB merupakan pengembangan dari Urea Molasses Blok (UMB). Komposisi MNB tersusun atas molasses 50\%, tepung hijauan jagung $30 \%$, urea $4 \%$, tepung cangkang kerang $3 \%$, tepung cangkang telur $3 \%$, garam 3\% dan bentonit $7 \%$.

Darah merupakan cairan didalam tubuh mahluk hidup yang berfungsi sebagai tranportasi zat - zat dan oksigen. Darah juga mengangkut sisa hasil metabolisme dan pertahanan tubuh terhadap virus atau penyakit. Protein plasma darah tersusun atas albumin, fibrinogen dan globulin (Widhyari et al., 2011). Albumin berfungsi untuk menjaga tekanan osmosis darah. Fibrinogen merupakan zat yang membantu dalam koagulasi darah (pembekuan darah). Globulin adalah protein darah yang berfungsi sebagai prekursor zat imun. Beberapa protein plasma darah yang disintesis di dalam hati antara lain albumin, globulin, dan fibrinogen (Jacob dan Rumlaklak, 2010).

Albumin merupakan protein terbesar di darah. Jumlah albumin di dalam protein serum darah hewan sekitar $35-50 \%$ (Irfan et al., 2014). Albumin juga berfungsi sebagai alat transport mineral seperti $\mathrm{Zn}$ yang akan mengaktifkan enzim untuk pembentukan produk ternak (Widhyari, 2012). Albumin berikatan kuat dengan 60\% hormon estradiol dan 38\% hormon testosteron yang berfungsi sebagai hormon reproduksi pada ternak (Narulita et al., 2016). Penurunan dan kenaikan kadar albumin darah dipengaruhi oleh asupan protein ke dalam tubuh, kondisi saluran pencernaan, dan penyakit (Sasongko dan Moshollaeni, 2017).

Komposisi globulin dalam plasma darah sekitar $35 \%$ dan diproduksi di hati dan sistem kekebalan antara lain kelenjar getah bening, limfa dan sumsum tulang. Globulin terbagi menjadi tiga yaitu alfa globulin, beta globulin, gamma globulin, macroglobulin dan transkobalamin. Globulin berfungsi sebagai sirkulasi ion, hormon, dan asam lemak pada sistem kekebalan, selain itu juga sebagai antibodi (Irfan et al., 2014). Globulin berikatan dengan hormon 60\% hormon testosteron dan 38\% hormon estradiol dalam serum darah (Narulita $e t$ al., 2016). Penurunan kadar glubolin disebabkan karena malnutrisi berat ataupun penyakit gastrointestinal, sedangkan peningkatannya karena terjadinya infeksi bakterial, virus, maupun dehidrasi (Yazid et al., 2000). Perbandingan A/G dalam darah untuk mengetahui apakah perlakuan berupa pemberian MNB aman atau tidak.

Penelitian ini bertujuan untuk mengkaji pengaruh pemberian MNB terhadap produktivitas kambing lokal tercermin melalui tingkat kecernaan dan kesehatan. Evaluasi dilakukan dengan cara menganalisis kadar albumin, globulin dan perbandingan $\mathrm{A} / \mathrm{G}$ di darah sebagai dugaan awal peningkatan produktivitas ternak. Manfaat dari penelitian ini yaitu untuk mengkaji peningkatan produktivitas kambing lokal dengan pemberian MNB.

\section{MATERI DAN METODE}

Penelitian dilaksanakan selama lima bulan di kandang percobaan Desa Mrunten Kel. Kalisidi, Kab.Ungaran dan analisis laboratorium dilaksanakan di Laboratorium Ilmu 
Nutrisi Ternak Fakultas Peternakan dan Pertanian, Universitas Diponegoro, Semarang dan Laboratorium IBL, Semarang.

Materi yang digunakan dalam penelitian ini antara lain obat cacing yang digunakan untuk membersihkan saluran pencernaan kambing dari cacing, multinutrien blok (MNB) yang digunakan sebagai pakan pelengkap. Ransum yang digunakan sebagai pakan utama, alkohol yang digunakan sebagai antiseptik setelah pengambilan darah dan 12 ekor kambing lokal jantan umur 7 bulan sehat secara klinis dengan 4 perlakuan level MNB yang berbeda. Alat yang digunakan 12 buah set lengkap kandang individu dengan yang digunakan sebagai tempat ternak, 12 buah spet $10 \mathrm{ml}$ dan jarum suntik yang digunakan untuk mengambil darah, label yang digunakan untuk memberi kode pada sampel, 12 buah tabung vacuulab tanpa EDTA untuk menampung darah sementara, cooling box untuk tempat penyimpanan sementara sampel darah.

Metode yang dilakukan dalam penelitian terdiri dari fase persiapan, adaptasi, prelim, perlakuan, dan pengambilan data. Dua belas (12) ekor kambing lokal umur 7 bulan dipelihara dalam kandang individu dan diadaptasikan selama 2 bulan. Awal kambing masuk diberikan obat cacing untuk membersihkan saluran pencernaan kambing dari cacing yang dapat mengganggu produktivitas ternak. Kambing diberi pakan 2 kali sehari yang tersusun atas hijauan dan konsentrat, selain itu juga disediakan air minum secara ad-libitum. Kambing ditimbang dan dikelompokkan berdasarkan bobot badan (BB) ke dalam 3 kelompok yaitu BB 17,5 - $20 \mathrm{~kg}$ (Kelompok I), 15 - 16,5 kg (Kelompok II), 13,5 - 15 kg (Kelompok III). Kambing diberikan ransum perlakuan selama 2 bulan yang disusun sesuai bobot badan ternak saat memasuki prelim. Ransum diberikan secara terukur (measured) sesuai kebutuhan ternak menurut bobot badan. Masa perlakuan Kambing diberikan ransum perlakuan dan level MNB selama 1 bulan. Perlakuan I berupa ransum tanpa MNB perlakuan II ransum dengan penambahan MNB 5 gram, perlakuan III ransum dengan penambahan MNB 10 gram, dan perlakuan IV ransum dengan penambahan MNB 15 gram. Setelah 1 bulan kambing diambil sampel darahnya dan dianalisis kadar albumin, globulin dan perbandingan $\mathrm{A} / \mathrm{G}$ untuk mengetahui pengaruh pemberian MNB. Pengambilan darah kambing dilakukan setelah kambing diberi pakan, darah diambil sebayak 2 $3 \mathrm{ml}$ tiap ekornya menggunakan spet dan jarum suntik. Sampel darah dimasukkan ke dalam tabung vacuulab kemudian dimasukkan ke dalam cooling box.

Variabel bebas dalam penelitian adalah level penambahan MNB, variabel kontrol adalah kambing pada tiap kelompok tanpa pemberian MNB, dan variabel terikat adalah hasil analisis kadar globulin serum darah kambing lokal. Data hasil analisis globulin serum darah kambing lokal diuji signifikasinya menggunakan ANOVA, apabila hasilnya berbeda nyata maka akan diuji lebih lanjut dengan uji Duncan's New Multiple Range Test (MRT).

Rancangan penelitian yang digunakan yaitu rancangan acak kelompok (RAK) dengan 4 perlakuan dan 3 ulangan. Parameter yang diamati yaitu Perubahan kadar globulin di dalam serum darah kambing lokal.

\section{Model Linier Aditif}

$$
\mathrm{Y}_{\mathrm{ij}} \quad=\mu+\tau_{\mathrm{i}}+\beta_{\mathrm{j}}+\varepsilon_{\mathrm{ij}}
$$

Keterangan :

$$
\begin{aligned}
& \mathrm{i}=1,2,3,4 \\
& \mathrm{j}=1,2,3 \\
& \mathrm{i}, \mathrm{j} \quad 1,2, \ldots, \mathrm{n} \\
& \text { Yij }=\text { Hasil perubahan kadar globulin yang } \\
& \text { memperoleh perlakuan level } \\
& \text { Multinutrisi Blok (MNB) ke-i pada } \\
& \text { kelompok ke-j. } \\
& \mu=\text { Rataan umum } \\
& \tau \mathrm{i}=\text { Pengaruh perlakuan level Multinutrisi } \\
& \text { Blok (MNB) ke- i } \\
& \beta_{\mathrm{j}}=\text { Pengaruh aditif kelompok ke- } \mathrm{j} \\
& \varepsilon \mathrm{ij}=\text { Galat percobaan perlakuan level } \\
& \text { Multinutrisi Blok (MNB) ke-i pada } \\
& \text { kelompok ke-j. }
\end{aligned}
$$

\section{HASIL DAN PEMBAHASAN}

Hasil analisis kadar albumin dan globulin pada serum darah kambing lokal setelah perlakuan level pemberian multinutrien blok (MNB) dapat dilihat pada Gambar 1.

\section{Albumin dan globulin}

Berdasarkan hasil analisis kadar albumin dan globulin serum darah kambing yang diberi perlakuan berbagai level MNB mulai dari 0, 5, 10, dan 15 gram dapat dilihat pada Gambar 1. Berdasarkan data Gambar 1 diketahui bahwa kadar albumin serum darah kambing lokal pada perlakuan kontrol (ransum tanpa MNB) kadar albumin sejumlah 2,60 g/dl, perlakuan I (ransum + 5 gram MNB) sebesar 2,37 g/dl, perlakuan II 


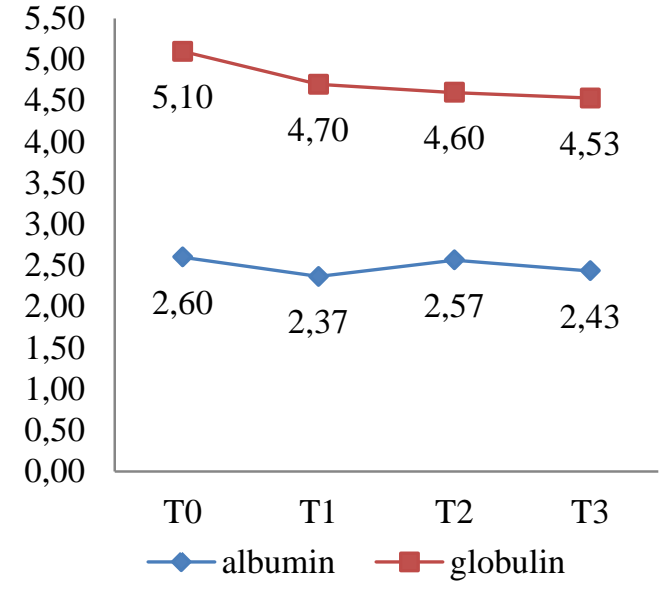

$\mathrm{T} 0=$ Ransum tanpa MNB $; \mathrm{T} 1=$ Ransum +5 gram MNB ; T2 = 10 gram MNB; T3 = Ransum + 15 gram MNB ; highly significant $=(\mathrm{P}<0.01)$; significant $=$ $(\mathrm{P}<0.05) ;$ non significant $=(\mathrm{P}>0.05)$

Gambar 1. Kadar rerata albumin dan globulin (g/dl) serum darah kambing

(ransum + 10 gram MNB) sebesar 2,57 g/dl, dan perlakuan III (ransum + 15 gram MNB) sebesar 2,43 g/dl. Kadar albumin serum darah kambing tertinggi terdapat pada perlakuan kontrol berupa ransum tanpa pemberian MNB.

Disimpulkan bahwa pemberian Multinutrisi Blok (MNB) tidak berpengaruh nyata $(p>0,05)$ terhadap peningkatan kadar albumin dalam darah namun kadar setiap perlakuan dalam taraf normal. Menurut
Widiyono et al. (2013) bahwa kadar albumin didalam serum darah kambing dinyatakan sehat (normal) berkisar antara 1,83-4,45 g/dl. Dapat disimpulkan bahwa pemberian MNB tidak meningkatkan tingkat kecernaan pakan.

Berdasarkan Gambar 1 kadar globulin serum darah kambing lokal pada perlakuan kontrol (ransum tanpa MNB) sejumlah 5,10 g/dl, perlakuan I (ransum +5 gram MNB) sebesar $4,70 \mathrm{~g} / \mathrm{dl}$, perlakuan II (ransum +10 gram MNB) sebesar 4,60 g/dl, dan perlakuan III (ransum +15 gram MNB) sebesar 4,53 g/dl. Kadar globulin serum darah kambing tertinggi terdapat pada perlakuan kontrol berupa ransum tanpa pemberian MNB. Disimpulkan bahwa pemberian Multinutrisi Blok (MNB) tidak berpengaruh nyata $(\mathrm{P}>0,05)$ terhadap peningkatan kadar globulin dalam darah namun kadar setiap perlakuan dalam taraf normal. Menurut Widiyono et al. (2013) kadar normal globulin di dalam serum darah kambing yang dikatakan sehat berkisar antara 3,51 - 5,85 g/dl. Dapat disimpulkan bahwa pemberian MNB tidak meningkatkan tingkat kesehatan ternak, namun ternak pada penelitian ini tetap dinyatakan sehat.

Produktivitas ternak tidak meningkat secara signifikan akibat pemberian MNB. Albumin dan globulin merupakan produk ternak. Albumin, globulin dan fibrinogen disintesis di dalam hati (Jacob dan Rumlaklak, 2010).

Tabel 1. Rerata kecernaan bahan organik (\%) kambing lokal

\begin{tabular}{ccccc}
\hline \multirow{2}{*}{ Perlakuan } & \multicolumn{3}{c}{ Kelompok } & \multirow{2}{*}{ Rerata } \\
\cline { 2 - 4 } & 1 & 2 & 3 & 78,634 \\
T0 & 81,032 & 81,965 & 72,905 & 77,392 \\
T1 & 77,543 & 81,791 & 72,843 & 77,246 \\
T2 & 79,515 & 73,519 & 78,703 & 75,948 \\
T3 & 80,546 & 71,428 & 75,871 & \\
\hline
\end{tabular}

Tabel 2. Analisis kalsium (Ca) dalam darah

\begin{tabular}{cccccc}
\hline \multirow{2}{*}{ Perlakuan } & \multicolumn{3}{c}{ Kelompok } & \multirow{2}{*}{ Jumlah } & \multirow{2}{*}{ Rataan } \\
\cline { 2 - 4 } & I & II & III & & \\
\hline --------------------- & mg/L & \\
\hline = tanpa MNB & 116,2 & 116,1 & 115,9 & 348,2 & 116,07 \\
$1=5$ gram MNB & 115,9 & 116,0 & 116,3 & 348,2 & 116,07 \\
$2=10$ gram MNB & 116,0 & 116,1 & 116,6 & 348,7 & 116,23 \\
$3=15$ gram MNB & 116,0 & 116,4 & 116,2 & 348,6 & 116,20 \\
\hline
\end{tabular}


Tabel 3. Analisis Zinc (Zn) dalam darah

\begin{tabular}{lccccc}
\hline \multirow{2}{*}{ Perlakuan } & \multicolumn{3}{c}{ Kelompok } & \multirow{2}{*}{ Jumlah } & \multirow{2}{*}{ Rataan } \\
\cline { 2 - 5 } & I & II & III & & \\
\hline 0 = tanpa MNB & 0,245 & 0,161 & 0,147 & 0,553 & 0,1843 \\
$1=5$ gram MNB & 0,110 & 0,127 & 0,118 & 0,355 & 0,1183 \\
$2=10$ gram MNB & 0,114 & 0,129 & 0,122 & 0,365 & 0,1217 \\
$3=15$ gram MNB & 0,117 & 0,126 & 0,133 & 0,376 & 0,1253 \\
\hline
\end{tabular}

Kelompok I $=$ BB rata - rata 18,$75 ;$ Kelompok II $=$ BB rata - rata 15,625; Kelompok III $=$ BB rata - rata 14,5 ; T0: Ransum tanpa MNB, T1: Ransum + MNB 5 gram, T2: Ransum + MNB 10 gram, T3: Ransum + MNB 15 gram $;$ highly significant $=(\mathrm{P}<0.01) ;$ significant $=(\mathrm{P}<0.05) ;$ non significant $=(\mathrm{P}>0.05)$

Tidak adanya peningkatan produk (albumin dan globulin) secara signifikan karena tidak adanya peningkatan subtrat terserap dan mineral terserap (Tabel 1, 2 dan 3). Substrat terserap berupa kecernaan bahan organik sebagai bahan utama sintesis produk sedangkan mineral berperan sebagai kofaktor enzim yang membantu proses sintesis. Menurut Widhyari (2012) bahwa mineral berfungsi sebagai kofaktor berbagai enzim, sintesis DNA, memberikan struktur dan integritas sel.

\section{Perbandingan A/G}

Berdasarkan hasil analisis perbandingan A/G serum darah kambing yang diberi perlakuan berbagai level MNB mulai dari 0, 5, 10, dan 15 gram dapat dilihat pada Tabel 4.

Tabel 4. Kadar perbandingan A/G serum darah kambing

\begin{tabular}{lccccc}
\hline \multirow{2}{*}{\multicolumn{1}{c}{ Perlakuan }} & \multicolumn{3}{c}{ Kelompok } & \multirow{2}{*}{ Jumlah } & Rata - rata \\
\cline { 2 - 4 } & I & II & III & & \\
\hline Ransum tanpa MNB & 0,46 & 0,57 & 0,51 & 1,54 & 0,51 \\
Ransum + 5 gram MNB & 0,49 & 0,51 & 0,51 & 1,51 & 0,50 \\
Ransum + 10 gram MNB & 0,62 & 0,59 & 0,48 & 1,69 & 0,56 \\
Ransum + 15 gram MNB & 0,51 & 0,59 & 0,52 & 1,62 & 0,54 \\
\hline
\end{tabular}

Kelompok I = BB 18,75 ; Kelompok II = BB 15,625 ; Kelompok III = BB 14,5 ; T0: Ransum tanpa MNB, T1: Ransum + MNB 5 gram, T2: Ransum + MNB 10 gram, T3: Ransum + MNB 15 gram ; highly significant = $(\mathrm{P}<0.01) ;$ significant $=(\mathrm{P}<0.05) ;$ non significant $=(\mathrm{P}>0.05)$

Berdasarkan data diketahui bahwa
pemberian MNB pengaruh pemberian Multinutrien Blok (MNB) tidak berpengaruh nyata $(\mathrm{p}>0,05)$ terhadap perbandingan kadar $\mathrm{A} / \mathrm{G}$ dalam darah. Hal ini menujukkan bahwa MNB aman dikonsumsi kambing karena tidak merubah status protein darah. Menurut Sultana dan Najam (2013) bahwa apabila perbandingan albumin dan globulin terlalu rendah maka akan mengakibatkan penyakit autoimmune dan sindrom nefrotik. Menurut Alberghina et al. (2010) bahwa apabila terjadi perubahan yang significan dalam ratio $\mathrm{A} / \mathrm{G}$ perlu diwaspadai dan diperhatikan secara khusus karena ditakutkan ternak terjangkit penyakit disproteinemia.

\section{KESIMPULAN}

Berdasarkan hasil penelitian diketahui bahwa pemberian multinutrien blok (MNB) tidak berpengaruh nyata terhadap perubahan status kadar albumin dan globulin dalam serum darah kambing lokal. Hal ini menunjukkan bahwa pemberian MNB tidak meningkatkan produktivitas dan imunitas kambing lokal secara signifikan. Dapat disimpulkan juga bahwa MNB aman untuk dikonsumsi ternak karena tidak mengubah perbandingan $\mathrm{A} / \mathrm{G}$ dalam serum darah kambing secara signifikan. Untuk penelitian selanjutnya perlu adanya perlu adanya pengembangan dengan penggunaan berbagai status fisiologis kambing atau pengurangan kandungan nutrien di dalam ransum.

\section{UCAPAN TERIMA KASIH}

Terima kasih saya ucapkan kepada seluruh pihak terlibat dalam penelitian ini terutama jajaran dosen Laboratorium Teknologi Pakan dan Laboratorium Ilmu Nutrisi Ternak 
terutama kepada Dr. Ir. Retno Iswarin Pujaningsih M.Agr.Sc dan Prof. Dr. Ir. Widiyanto S. U. selaku dosen Pembimbing penelitian sehingga penelitian ini dapat berjalan lancar.

\section{DAFTAR PUSTAKA}

Alberghina, D., S. Casella, I. Vazzana, V. Ferrantelli, C. Giannetto dan Piccione. Analysis of serum proteins in clinically healthy goats (Capra hircus) using agarose gel electrophoresis. American Society Veterinary Clinical Pathology. 39 (3) : $317-321$.

Faizal. 2008. Respon pemberian multi mineral blok (MMB) terhadap pertambahan bobot badan sapi bali. Jurnal Ilmiah Ilmu-Ilmu Peternakan. 11 (2) : $66-69$.

Irfan, I. Z., A. Esfandiari, dan C. Choliq. 2014. Profil protein total, albumin, globulin dan rasio albumin dan globulin sapi pejantan bibit. JITV. 19 (2) : 123 - 129.

Jacob, J. M. dan Y. Y. Rumlaklak. 2010. Pemeriksaan laju endap darah (LED) sebagai indikator terhadap abnormalitas organ hati kambing lokal. Partner. 17 (2) : 153-161.

Kurnianto, E. 2010. Pemuliaan Ternak. Graha Ilmu, Yogyakarta.

Narulita, E., J. Prihatin dan R. S. Dewi. 2016. Pemanfaatan hasil induksi hormon estrogen terhadap kadar estradiol dan histologi uterus mencit (Mus musculus) sebagai buku suplemen sistem reproduksi di SMA. Jurnal Bioedukatika. 4 (2) : 1 7 .

Sasongko, P. dan W. Mushollaeni. 2017. Efek paparan alginat dalam pangan terhadap kadar protein total, albumin dan globulin darah. Buana Sains 17 (2) : 189 - 196.

Sultana, N dan R. Najam. 2013. Alteration in total protein concentration, serum protein fraction and albumin / globulin ratio in healthy rabbits. International Research Journal Of Pharmacy. 4 (8) : $128-130$.

Widhyari, S. D., A. Esfandiari dan Herlina. 2011. Profil protein total, albumin dan globulin pada ayam broiler yang diberi kunyit, bawang putih dan Zinc (Zn). Jurnal Ilmu Pertanian Indonesia. 16 (3) : 179 - 184.

Widhyari, S. D. 2012. Peran dan dampak defisiensi zinc (Zn) terhadap sistem tanggap kebal. Wartazoa. 22 (3) : 141 148.

Widiyono, I., Sarmin dan B. Suwignyo. 2013. Respons metabolik terhadap pembatasan asupan pakan pada kambing peranakan ettawa. Jurnal Veteriner. 14 (4) : $424-$ 429.

Yazid, M., Triyono dan A. Bastianudin. 2000. Penentuan beberapa parameter kimia klinik darah untuk evaluasi kondisi kesehatan pekerja radiasi. Prosiding Pertemuan dan Presentasi Ilmiah Penelitian Dasar Ilmu Pengetahuan dan Teknologi Nuklir. P3TM - BATAN, Yogyakarta. Tanggal. 25 - 26 Juli 2000. Hal. 67- 72. 